\title{
PENGARUH KESADARAN MEREK, ASOSIASI MEREK DAN PERCEPTION OF QUALITY TERHADAP KEPUTUSAN PEMBELIAN HOSPITAL BED MEREK PARAMOUT DI PT. AGA MEDIKA UTAMA PADANG (Studi Kasus Rumah Sakit Umum Kota Padang)
}

\author{
Yola Nirmala, Riri Mayliza \\ Sekolah Tinggi Ilmu Ekonomi "KBP" \\ ririmayliza@akbpstie.ac.id
}

\begin{abstract}
Decision purchase hospital bed brand paramount at PT. Aga Medika Utama in public hospitals in Padang city experienced an increase in seeing the phenomenon get an idea about a research with the theme of brand awareness, brand association and perception of quality to purchase decision of hospital bed.In the study, the authors create independent variables consisting of brand awareness (X1), Brand Association (X2) and Perception of Quality as (X3) while the dependent variable is the purchase decision $(Y)$. Of all variables are used multiple regression tests. The results of the study illustrate that X1 and X3 show significant value smaller than 0.05 so that the hypothesis given the researchers can be accepted. As for X2 showed significant value greater than 0.05 this indicates that the value is not acceptable by the researcher hypothesis. It can be concluded that brand awareness and quality perception are positively associated with purchasing decisions. As for the brand association of purchasing decisions have a negative effect.
\end{abstract}

Keywords: brand awareness, Brand Association, Perception of Quality and purchase decision

\section{PENDAHULUAN}

Dengan adanya kebijakan pemerintah yang memfokuskan untuk mempermudah masyarakat luas dalam menerima layanan pengobatan dengan membuat program BPJS, membuat pasien yang berobat ke rumah sakit semakin meningkat setiap tahunnya. Hal tersebut membuat kebutuhan akan alat-alat kesehatan juga ikut meningkat. Salah satu alat kesehatan yang sangat dibutuhkan yaitu Hospital Bed, karena setiap ruangan di rumah sakit umum kota Padang seperti RSUP. DR. M. Djamil Padang, RSU. Semen Padang dan RSU. Siti 
Rahmah memerlukan hospital bed dengan jumlah yang berbeda sesuai dengan kelasnya.

Dari tabel market share diatas pun dapat dilihat bahwa Paramount Bed merupakan market leader (pemimpin pasar) dari kuartal tiga 2015 sampai kuartal dua 2016. Pada kuartal tiga 2015, penjualan Paramount Bed berada pada 23,30\% mengalami penurunan pada kuartal empat 2015 menjadi 20,40\%. Pada kuartal satu 2016, penjualan Paramount Bed mengalami peningkatan menjadi 23,80\% serta mengalami penurunan pada kuartal dua 2016 menjadi 22,80\%. Ini menunjukkan bahwa keputusan pembelian tidak stabil dari kuartal tiga 2015 sampai kuartal dua 2016.

Dari data di atas dapat dilihat, setiap rumah sakit memiliki kebutuhan yang berbeda, semua tergantung kepada jumlah pasiennya. Penjualan terbanyak terdapat pada RSUP. DR. M. Djamil dikarenakan Rumah Sakit ini memiliki banyak pasiennya. Namun penjualan hospital bed paramount mengalami siklus naik turun. Lain halnya pada RSU. Semen Padang dan RSU. Siti Rahmah, walaupun penjualan hospital bed tidak terlalu banyak, namun mereka konsisten terhadap penggunaan produk hospital bed paramount. Dan selalu mengalami kenaikan penjualan disetiap bulannya.

Berdasarkan uraian diatas, maka penulis tertarik untuk meneliti dalam penelitian ini dengan judul "Pengaruh Kesadaran Merek, Asosiasi Merek dan Perception of Quality terhadap Keputusan Pembelian Hospital Bed Merek Paramount di PT. Aga Medika Utama Padang (Studi Kasus Rumah Sakit Umum di Kota Padang).

Berdasarkan uraian latar belakang diatas, maka masalah pada penelitian ini adalah : 1. Apakah kesadaran merek berpengaruh terhadap keputusan pembelian Hospital Bed Paramount di PT. Aga Medika Utama?

2. Apakah asosiasi merek berpengaruh terhadap keputusan pembelian Hospital Bed Paramount di PT. Aga Medika Utama? 3. Apakah persepsi kualitas berpengaruh terhadap keputusan pembelian Hospital Bed Paramount di PT. Aga Medika Utama?

\section{KAJIAN TEORI}

\section{Kesadaran Merek}

Kesadaran merek (brand awareness) menunjukkan kemampuan seorang konsumen untuk mngetahui dan mengingat suatu merek sebagai bagian dari suatu kategori produk tertentu. Kesadaran merek terdiri atas beberapa unsur yaitu puncak pikiran (top if mind), mengingat kembali merek (brand recall), mengenali merek (brand recognition), dan tidak mengenal merek (brand unaware). Puncak pikiran adalah suatu konsep yang memperlihatkan merek apa yang pertama kali diingat atau muncul dalam pikiran konsumen ketika ia ditanya untuk menyebutkan suatu merek dari kategori produk tertentu. Ketika konsumen menyebutkan merek kedua, merek ketiga, dan merek lainnya dari kategori produk ditanyakan tersebut, maka merek-merek tersebut sebagai brand recall.

Berdasarkan pendapat para ahli diatas, dapat disimpulkan bahwa kesadaran merek merupakan kesanggupan seorang calon pembeli untuk mengenali dan mengingat produk yang akan dibeli 


\section{Asosiasi Merek}

Sumarwan (2013:133) menyatakan asosiasi merek adalah persepsi konsumen mengenai beragam atribut atau citra atau kesan yang dimiliki oleh atau terkait dengan suatu merek tersebut. Ketika seorang konsumen mengingat suatu merek maka ingatan tersebut akan dikaitkan dengan persepsinya terhadap merek tersebut. Seorang konsumen akan memiliki banyak persepsi mengenai merek tersebut jika konsumen tersebut telah mengenal atau telah lama menggunakan merek tersebut. Beragam kesan atau citra yang dipersepsikan konsumen terhadap suatu merek akan membentuk citra merek.

Dalam jurnal Pujotomo (2014) brand association adalah segala kesan yang muncul dibenak seseorang yang terkait dengan ingatannya mengenai suatu merek. Kesan-kesan yang terkait merek akan semakin menginat dengan semakin banyaknya pengalaman konsumen dalam mengkonsumsi suatu merek atau dengan semakin seringnya penampakan merek tersebut dalam strategi komunikasinya.

Berdasarkan pendapat para ahli diatas, dapat disimpulkan bahwa asosiasi merek merupakan kesan yang muncul di benak konsumen setelah melakukan penilaian terhadap hospital bed merek Paramount dibandingkan dengan merek hospital bed lainnya.

\section{Perception of Quality}

Sumarwan (2013:142), menyatakan perception Of Quality ( Persepsi kualitas ) adalah persepsi konsumen terhadap kualitas suatu barang atau jasa. Konsumen akan memiliki persepsi yang baik mengenai kualitas ketika barang atau jasa tersebut dinilai memenuhi harapan konsumen. Bagi seorang konsumen, kualitas akan memiliki banyak arti. Kualitas yang baik dapat diartikan bahwa barang atau jasa tersebut memiliki keunggulan dibandingkan brang atau jasa lainnya. persepsi kualitas merek dapat dipandang sebagai persepsi menyeluruh terhadap suatu merek produk. Konsumen sering kali memiliki satu persepsi tentang suatu merek, misalnya dia menganggap suatu merek lebih baik kualitasnya menyebutkan atribut mana yang dianggap lebih baik, juga sering kali tidak dapat secara terperinci mengemukakan apa yang dimaksud kualitas lebih baik tersebut.

Persepsi kualitas mencerminkan perasaan pelanggan secara menyeluruh mengenai suatu merek. Persepsi pelanggan akan melibatkan apa yang penting bagi pelanggan karena setiap pelanggan atau konsumen memiliki kepentingan yang berbeda-beda terhadap suatu produk atau jasa. Persepsi kualitas suatu merek dapat dipahami melalui pengukuran dimensi yang terkai dengan karakteristik (Durianto dalam jurnal Desiana, 2015)

Berdasarkan definisi para ahli diatas, dapat disimpulkan bahwa persepsi kualitas merupakan persepsi konsumen terhadap keseluruhan kualitas atau keunggulan suatu produk atau jasa yang sama dengan maksud yang diharapkannya

\section{Keputusan Pembelian}

Pada dasarnya keputusan pembelian sangat dipengaruhi oleh motif-motif pembelian duimana bisa karena pembeli melaksanakan pembelian hanya mempertimbangkan motif atau dorongan secara emosional seperti bangga, sugesti, dan sebagainya akan tetapi konsumen membeli secara rasional seperti kualitas maupun harganya.

Menurut Alma (2011:96), keputusan pembelian merupakan suatu keputusan konsumen yang dipengaruhi oleh ekonomi, teknologi, politik, budaya, produk, harga, lokasi, promosi, physical evidence, people dan process sehingga 
membentuk suatu sikap pada konsumen untuk mengolah segala informasi dan mengambiol kesimpulan berupa respons yang muncul produk apa yang akan dibeli.

Menurut Schiffman dan Kanuk dalam Sangadji (2013:120), mendefinisikan keputusan sebagai pemilihan suatu tindakan dari dua pilihan alternati atau lebih. Seorang konsumen yang hendak memilih harus memiliki pilihan alternatif. Sedangkan menurut Tjiptono (2011:25), keputusan pembelian konsumen merupakan pemilihan satu tindakan dari dua atau lebih alternatif.

\section{Hipotesis}

Dari hasil penelitian Desiana (2015) menunjukkan bahwa kesadaran merek berpengaruh positif dan signifikan terhadap keputusan pembelian. Berdasarkan tinjauan pustaka dan penelitian terdahulu yang telah diuraikan diatas, maka hipotesis yang akan dikembangkan dalam penelitian ini adalah sebagai berikut: 1.Diduga kesadaran merek berpengaruh positif dan signifikan terhadap keputusan pembelian Hospital Bed Paramount pada PT.Aga Medika Utama. 2.Diduga asosiasi merek berpengaruh positif terhadap keputusan pembelian Hospital Bed Paramount pada PT.Aga Medika Utama. 3.Diduga persepsi kualitas berpengaruh positif terhadap keputusan pembelian Hospital Bed Paramount pada PT. Aga Medika Utama.

\section{METODE PENELITIAN}

\section{Jenis Penelitian}

Dalam penelitian ini dilakukan pada rumah sakit umum di kota Padang yang sebagai konsumen PT.Aga Medika Utama dalam pembelian Hospital Bed. Jenis penelitian yang dilakukan oleh peneliti adalah Penelitian kuantitatif Penelitian kuantitatif adalah pendekatan ilmiah yang memandang suatu realitas itu dapat diklasifikasikan, konkrit, teramati dan terukur, hubungan variabelnya bersifat sebab akibat dimana data penelitiannya berupa angka-angka dan analisisnya menggunakan statistik (Sugiono,2008). Dalam hal ini ada variabel independent (variabel yang mempengaruhi) dan ada variabel dependent (dipengaruhi). Hubungan yang terjadi yaitu asimetris, dimana variabel bebas adalah kesadaran merek, asosiasi merek dan persepsi kualitas yang berpengaruh terhadap variabel terikat yaitu keputusan pembelian pada konsumen PT.Aga Medika Utama.

\section{Populasi dan Sampel}

Populasi dalam penelitian ini adalah tiga Rumah Sakit Umum di Kota Padang yaitu RSUP. DR. M. Djamil Padang, RSU. Semen Padang dan RSU. Siti Rahmah yang melakukan pembelian hospital bed pada PT.Aga Medika Utama.

Menurut Sunyoto (2012) sampel adalah sebagian dari populasi yang karakteristiknya hendak diteliti, dan dianggap bisa mewakili keseluruhan pupulasi. Dalam penelitian ini yang menjadi sampel adalah RSUP. DR. M. Djamil Padang, RSU. Semen Padang dan RSU. Siti Rahmah yang membeli hospital bed Paramount pada PT. Aga Medika Utama yang bersedia menjadi sampel dalam penelitian ini. Teknik pengambilan sampel dalam penelitian ini menggunakan teknik Simple Random Sampling, yaitu pengambilan sampel dengan cara acak sederhana melalui daftar bilangan random. 


\section{ANALISA DAN PEMBAHASAN}

\section{Gambaran Umum Penelitian}

Paramount Bed adalah produsen tempat tidur rumah sakit terkemuka dan perusahaan perawatan kesehatan bertekonologi tinggi dengan reputasi yang sangat baik dalam bidang kesehatan. Paramount Bed memiliki jaringan global yang luas yang melayani kebutuhan klien di seluruh dunia. Dalam pendistribusian paramount bed di Sumatera Barat yang menjadi distributornya tunggal adalah PT. Aga Medika Utama.

PT. Aga Medika Utama telah mendistribusikan Paramount Bed hampir diseluruh rumah sakit di Sumatera Barat. Karena banyak begitu banyaknya rumah sakit di Sumatera Barat, maka dalam penelitian ini, peneliti hanya mengambil populasi dan sampel dari beberapa rumah sakit yang di Kota Padang.

Rumah sakit yang menjadi sampel adalah RSUP. DR. M. Djamil Padang, RSU. Semen Padang dan RSU. Siti Rahmah. Yang menjadi responden adalah karyawan dirumah sakit tersebut dan kuesioner yang akan disebar sebanyak 70 . Dalam penyebaran kuesioner dilakukan secara acak dengan melihat banyak memiliki merek Paramount Bed di rumah sakit.

Dari kuesioner yang disebar sebanyak 70 buah, ternyata yang dapat diolah hanya 53 kuesioner, 17 kuesioner lagi tidak dapat diolah karena banyak data yang responden tidak di isi secara lengkap.

\section{Demografi Responden}

Demografi responden terbagi menjadi 3 karakteristik yang mana dijelaskan sebagai berikut:

Dilihat dari tabel 4.2 bahwa karakteristik responden berdasarkan jenis kelamin terdapat 23 responden atau $43,4 \%$ berjenis kelamin laki-laki sedangkan untuk responden perempuan sebanyak 30 atau 56,6\%. Dari hasil tersebut dapat disimpulkan bahwa responden yang terbanyak adalah perempuan walaupun hanya berbeda sedikit

Berdasarkan tabel 4.3 diketahui bahwa umur 31-35 adalah responden terbanyak yaitu 18 atau 34,0\% disusul dengan 16 responden atau 30,2 dengan umur 26-30. Dan untuk umur 20-25 hanya memiliki responden 6 atau 11,3\%, untuk umur 36-40 hanya 8 responden atau $15,1 \%$ sedangkan umurnya yang lebih dari 41 adalah 5 responden.

Dilihat dari hasil tabel 4.5 bahwa rumah sakit yang menjadi responden terbanyak ditempatkan di RSUP M.Djamil dengan 22 responden atau 41,5\%. Sedangkan untuk rumah sakit Siti Rahmah dan Semen Padang hanya selisih 1 responden, untuk rumah sakit Siti Rahmah 15 responden atau 28,3\% dan untuk rumah sakit Semen Padang 16 responden atau 30,2\%.

\section{HASIL PENELITIAN}

\section{Uji Normalitas}

Dari Tabel 4.16, terlihat bahwa nilai asymp.sig (2-tailed) menunjukkan nilai > dari 0.05 , yaitu 0.269 untuk X1, 0,179 untuk X2, 0,186 untuk X3 sedangkan untuk $\mathrm{Y}$ adalah 0,304 Dengan demikian data dapat dikatakan berdistribusi normal.

2. Uji Regresi Linier Berganda

Dari persamaan diatas dapat dilihat bahwa terdapat nilai konstanta sebesar 3,487 yang berarti bahwa tanpa ada kesadaran merek, asosiasi merek dan persepsi kualitas terhadap keputusan pembelian berada pada 3,487 satuan. Nilai koefisien 
dari variabel X1 adalah sebesar 0,506 ini berarti bahwa meningkatnya kesadaran merek pada satu satuan, maka akan meningkatkan keputusan pembelian sebesar 0,506. Nilai koefisien X2 adalah sebesar -0,804 ini berarti bahwa dengan menurunnya asosiasi merek pada satu satuan maka akan menurunkan keputusan pembelian sebesar $-0,804$ satuan. Nilai koefisien dari variabel X3 adalah sebesar 0,423 ini berarti bahwa meningkatnya persepsi kualitas satu satuan, maka akan meningkatkan keputusan pembelian sebesar 0,423 satuan.

3. Uji F

Untuk mengetahui pengaruh secara bersama-sama variabel independen terhadap variabel dependen dapat dilihat dari hasil uji regresi berganda, seperti dapat dilihat pada Tabel 4.18 Pengaruh secara bersama sama variabel independen terhadap variabel dependen dilakukan dengan cara membandingkan $\mathrm{F}$ tabel dan $\mathrm{F}$ hitung. Hipotesis diterima jika $\mathrm{F}$ hitung $>\mathrm{F}$ tabel dan nilai $\operatorname{sig}<\alpha 0,05$. Nilai $\mathrm{F}$ tabel pada $\alpha 0,05$ adalah 2,79. Nilai $F$ hitung adalah 39,312 sedangkan nilai sig adalah 0,000. Dengan demikian berarti $\mathrm{F}$ hitung $>\mathrm{F}$ tabel dan nilai sig $<\alpha 0,05$, yaitu 39,312 > 2,72, dan sig $0,000<\alpha 0,05$. Hal ini menunjukkan bahwa model regresi dapat digunakan untuk menguji pengaruh secara bersama-sama variabel independen terhadap variabel dependen, yaitu kesadaran merek, asosiasi merek, dan persepsi kualitas secara bersama-sama berpengaruh terhadap keputusan pembelian.

4. Uji T

1. Pengujian Hipotesis 1

Pengujian hipotesis 1 dilakukan dengan membandingkan nilai t hitung dan $\mathrm{t}$ tabel. Hipotesis diterima jika $\mathrm{t}$ hitung $>\mathrm{t}$ tabel atau nilai sig $<\alpha 0,05$. Nilai $\mathrm{t}$ tabel pada $\alpha=0,05$ adalah 1,6765 . Untuk variabel kesadaran merek (X1) nilai t hitung adalah 5,374 atau nilai sig adalah 0,000. Dengan demikian dapat dikatakan bahwa $\mathrm{t}$ hitung $>\mathrm{t}$ tabel, yaitu 5,374 $>1,6765$ atau nilai signifikansi $0,000<\alpha 0,05$. Nilai koefisien $\beta$ dari variabel X1 bernilai positif yaitu 0,506 . Hal ini menunjukkan bahwa penelitian ini dapat membuktikan kesadaran merek (X1) berpengaruh signifikan dan positif terhadap keputusan pembelian. Sehingga hipotesis pertama pada penelitian ini dapat diterima

2. Pengujian Hipotesis 2

Pengujian hipotesis 2 dilakukan dengan membandingkan nilai t hitung dan $\mathrm{t}$ tabel. Hipotesis diterima jika $\mathrm{t}$ hitung $>\mathrm{t}$ tabel atau nilai sig $<\alpha 0,05$. Nilai $\mathrm{t}$ tabel pada $\alpha=0,05$ adalah 1,6765 . Untuk variabel asosiasi merek (X2) nilai t hitung adalah $-0,804$ atau nilai sig adalah 0,425 . Dengan demikian dapat dikatakan bahwa t hitung $>\mathrm{t}$ tabel, yaitu $-0,804<1,6765$ atau nilai signifikansi $0,425>\alpha$ 0,05 . Nilai koefisien $\beta$ dari variabel X2 bernilai negatif yaitu $-0,063$ Hal ini menunjukkan bahwa penelitian ini dapat membuktikan asosiasi merek (X2) tidak berpengaruh signifikan dan negatif terhadap keputusan pembelian. Sehingga hipotesis kedua pada penelitian ini tidak dapat diterima

3. Pengujian Hipotesis 3

Pengujian hipotesis 3 dilakukan dengan membandingkan nilai $\mathrm{t}$ hitung dan $\mathrm{t}$ tabel. Hipotesis diterima jika $t$ hitung $>t$ tabel atau nilai sig $<\alpha 0,05$. Nilai $t$ tabel pada $\alpha=0,05$ adalah 1,6765. Untuk variabel persepsi kualitas (X3) nilai t hitung adalah 5,807 atau nilai sig adalah 0,000. Dengan demikian dapat dikatakan bahwa t hitung $>$ t tabel, yaitu 5,807 $>1,6765$ atau nilai signifikansi $0,000<\alpha 0,05$. Nilai koefisien $\beta$ dari variabel X3 bernilai positif yaitu 0,423 Hal ini menunjukkan 
bahwa penelitian ini dapat membuktikan persepsi kualitas (X3) berpengaruh signifikan dan positif terhadap keputusan pembelian. Sehingga hipotesis ketiga pada penelitian ini dapat diterima

\section{PEMBAHASAN}

Berdasarkan hasil penelitian yang dilakukan penelitian melalui hipotesis 1 maka dapat disimpulkan bahwa pengaruh kesadaran merek terhadap keputusan pembelian paramount bed berpengaruh signifikan karena dapat dilihat dari hasil uji $\mathrm{T}$ dengan hasil $0,000<\alpha 0,05$ yang mana untuk persyaratan dalam uji $\mathrm{t}$ signifikan adalah t tabel $<0,005$.

Berdasarkan hasil penelitian yang dilakukan penelitian melalui hipotesis 2 maka dapat disimpulkan bahwa pengaruh kesadaran merek terhadap keputusan pembelian paramount bed tidak begitu signifikan karena dapat dilihat dari hasil uji T dengan hasil 0,425 $>\alpha 0,05$ yang mana untuk persyaratan dalam uji t signifikan adalah $t$ tabel $<0,005$. Hal ini mungkin disebabkan karena kurangnya komunikasi atas perkenalan merek yang tidak begitu baik.

Sesuai dengan yang dikatakan Durianto dkk. (2004) kesan-kesan yang terkait merek akan semakin meningkat dengan semakin banyaknya pengalaman konsumen dalam mengkonsumsi suatu merek dengan semakin seringnya penampakan merek tersebut dalam strategi komunikasinya, ditambah lagi jika kaitan tersebut didukung oleh suatu jaringan dengan kaitan-kaitan lain.

Berdasarkan hasil penelitian yang dilakukan penelitian melalui hipotesis 3 maka dapat disimpulkan bahwa pengaruh kesadaran merek terhadap keputusan pembelian paramount bed tidak begitu signifikan karena dapat dilihat dari hasil uji $\mathrm{T}$ dengan hasil $0,000<\alpha 0,05$ yang mana untuk persyaratan dalam uji t signifikan adalah $\mathrm{t}$ tabel $<0,005$.

\section{KESIMPULAN DAN SARAN}

\section{Kesimpulan}

Setelah melihat teori dan membuat penelitian maka penulis ingin membuatkan kesimpulan dari penelitian pengaruh kesadaran merek, asosiasi merek dan persepsi kualitas terhadap keputusan pembelian Paramount Bed PT Aga Medika Utama sebagai berikut: 1. Pengaruh Kesadaran Merek terhadap Keputusan Pembelian Paramount Bed di PT Aga Medika Utama

Berdasarkan hasil penelitian yang dilakukan penelitian melalui hipotesis 1 maka dapat disimpulkan bahwa pengaruh kesadaran merek terhadap keputusan pembelian paramount bed berpengaruh signifikan karena dapat dilihat dari hasil uji $\mathrm{T}$ dengan hasil $0,000<\alpha 0,05$ yang mana untuk persyaratan dalam uji $\mathrm{t}$ signifikan adalah t tabel $<0,005$. 2.Pengaruh Asosiasi Merek terhadap Keputusan Pembelian Paramount Bed PT Aga Medika Utama

Berdasarkan hasil penelitian yang dilakukan penelitian melalui hipotesis 2 maka dapat disimpulkan bahwa pengaruh kesadaran merek terhadap keputusan pembelian paramount bed tidak begitu signifikan karena dapat dilihat dari hasil uji T dengan hasil $0,425>\alpha 0,05$ yang mana untuk persyaratan dalam uji t signifikan adalah $t$ tabel $<0,005$. Hal ini mungkin disebabkan karena kurangnya komunikasi atas perkenalan merek yang tidak begitu baik. 3.Pengaruh Persepsi Kualitas terhadap Keputusan Pembelian Paramount Bed PT Aga Medika Utama 
Berdasarkan hasil penelitian yang dilakukan penelitian melalui hipotesis 3 maka dapat disimpulkan bahwa pengaruh kesadaran merek terhadap keputusan pembelian paramount bed tidak begitu signifikan karena dapat dilihat dari hasil uji $\mathrm{T}$ dengan hasil $0,000<\alpha 0,05$ yang mana untuk persyaratan dalam uji t signifikan adalah $\mathrm{t}$ tabel $<0,005$.

2. Saran

Dari pembahasan dan kesimpulan yang diperoleh maka penulis memberikan saran sebagai berikut: 1.Bagi perusahaan yaitu, melalui penelitian ini dapat memberikan masukan terhadap keputusan pembelian paramount bed melalui persepsi kualitas dan mecari alternative lain dalam meningkatkan keputusan pembelian terhadap Paramount Bed. .Bagi peneliti selanjutnya penelitian dapat dikembangkan dengan mencari-cari variabel-variabel lain dalam keputusan pembelian.

\section{DAFTAR PUSTAKA}

Abdullah, T dan Francis Tantri. 2012. Manajemen Pemasaran. Raja Grafindo Persada.

Alma, Buchari. 2011. Manajemen Pemasaran dan Pemasaran Jasa. Bandung : Alfabeta.

Ardina Cahya Kusuma Dewi, 2014, Analisis Pengaruh Kesadaran Merek, Asosiasi Merek, Persepsi Kualitas, dan Loyalitas Merek Terhadap Keputusan Pembelian (Studi Kasus Pada Konsumen Produk Viva Hand \& Body Lotion di Kota Semarang), Fakultas Ekonomi dan Bisnis Universitas Diponegoro Semarang.

Desiana, Arnes. 2015. Pengaruh Kesadaran Merek, Persepsi Kualitas, Asosiasi Merek, Dan Loyalitas Merek Terhadap Keputusan Pembelian Pada Konsumen Tas Sophie Martin Di Bc Yulis Mawaddaty Pare. Jurnal : Universitas Nusantara PGRI Kediri.

Erviana, Indah Puji. 2013. Pengaruh Kesadaran Merek, Asosiasi Merek, Persepsi Kualitas, Loyalitas Merek Terhadap Ekuitas Merek (Survei Pada Warga Perumahan Joyo Grand Konsumen Air Minum Kemasan Merek Aqua Di Kota Malang). Jurnal : Universitas Brawijaya Malang.

Fatimah, Siti. 2013. Pengaruh Kesadaran Merek, Persepsi Kualitas, Asosiasi Merek, Dan Loyalitas Merek Terhadap Keputusan Pembelian Pelemban Wardah Pada Konsumen Al Yasin Mart Wonorejo. Jurnal : Universitas Yudharta Pasuruan.

Hasyim, Alex Prayogo. Analisis Pengaruh Kesadaran Merek, Asosiasi Merek, Persepsi Merek Dan Loyalitas Merek Terhadap Preferensi Merek Dan Niat Beli Pada Pasta Gigi Close Up Di Surabaya. Jurnal : Universitas Surabaya. 
Marlius, D. (2018). Pengaruh Dimensi Kualitas Pelayanan Website Akademik Terhadap Kepuasan Mahasiswa Pada STIE “KBP”. Jurnal Ipteks Terapan. Volume 12. No. 2. Hal. 116-128. http://doi.org/10.22216/jit.2018.v12i2.633

Marlius, D. (2017). Keputusan Pembelian Berdasarkan Faktor Psikologis Dan Bauran Pemasaran Pada PT. Intercom Mobilindo Padang. Jurnal Pundi. Volume 1. No. 1. Hal. 57-66. https://doi.org/10.31575/jp.v1i1.9

Marlius, D. (2016). Pengaruh Bauran Pemasaran Jasa Terhadap Minat Nasabah Dalam Menabung Pada Bank Nagari Cabang Muaralabuh. https://doi.org/10.31227/osf.io/vdqgx

Marlius, D. (2018). Loyalitas Nasabah Bank Nagari Syariah Cabang Bukittinggi Dilihat Dari Kualitas Pelayanan. Jurnal Pundi. Volume 1. No. 3. Hal.12-22. https://doi.org/10.31575/jp.v1i3.60

Nugroho,Stiadi, J. 2010. Perilaku Konsumen. Jakarta : Kencana

Pujotomo, Darminto. 2014. Analisis Pengaruh Kesadaran Merek, Asosiasi Merek, Persepsi Kualitas, Dan Loyalitas Merek Terhadap Ekuitas Merek Laptop (Studi Kasus Mahasiswa Universitas Diponegoro Semarang). Jurnal : Universitas Diponegoro.

Sangadji, Etta Mamang dan Sopiah.2013.Perilaku Konsumen.Yogyakarta : Andi.

Suharno. 2010. Pemasaran Jasa. Jakarta : Erlangga.

Sumarwan, Ujang. 2013. Riset Pemasaran dan Konsumen. Bogor : IPB Pers.

Sunyoto, Danang. 2015. Strategi Pemasaran. Jakarta : Buku Seru.

Sunyoto, Danang. 2012. Konsep Dasar Riset Pemasaran Dan Perilaku Konsumen. Yogyakarta : CAPS.

Tjiptono, Fandy. 2012. Pemasaran Strategik. Jakarta : Andi. 